\title{
THE TRUTH OF LIFE AND ART IN THE FATE OF A “SHUM BOLA”
}

\author{
Matluba Tokhirovna Norboboyeva
}

Teacher Of "Uzbek Language And Literature" Department, Shakhrisabz Branch Of Tashkent State Pedagogical University Named After Nizami

\section{ABSTRACT}

In this scientific article, the "Orphan Child" character in the story "Shum bola" by G. Gulam is studied as an object of research, the observation and artistic interpretation of spiritual experiences. It is an artistic analysis of the peculiarities of the child's psyche, an analysis of the orphan's mental anguish, emotions and experiences.

KEYWORDS:- "Orphan child", child psyche, emotional experience, "comic catharsis", grief, pain, suffering.

\section{INTRODUCTION}

An artistic image is formed as a result of the creative synthesis of various changes and experiences in the real being, in the human psyche, through the creative consciousness, worldview, aesthetic ideal, ideological purpose. Therefore, every new character created by the creator is a new creation, a new discovery. B. Sarimsakov says: "To create such an image, first of all, you need an objective basis in the material of reality, to put it simply, yeast. Second, how the chosen life material is portrayed or expressed depends on the artist's desires and goals, talents and skills [1]." The conscious reflection of certain individuals in reality through their spiritual world, emotional richness, and emotions creates an artistic image. Creating a truly artistic image is a great discovery. The character of a work of art depends on the aesthetic ideal of the writer. In the work of art, one can observe the domestic, social, and individual factors of the character of the "orphan child". There is a hidden critique behind the art in works written based on social reality. In the literature, the social factor of the image of the "orphan child" is the social environment in which the artist lives, the period, the reality he perceives. In general, a writer's ability to capture the events of his or her own life and to translate them into a work of art is a vital factor in the creation of an image. "There are some facts in the history of literature that an emergency in the life of an artist then goes beyond its individuality and begins to perform a universal function ." In the literature, the domestic factor is also one of the main motives in the formation of the character of the "orphan child" and contributes 
CURRENT RESEARCH JOURNAL OF PHILOLOGICAL SCIENCES 2(5): 43-47,

May 2021 DOI: https://doi.org/10.37547/philological-crjps-02-05-12

ISSN 2767-3758

(C)2021 Master Journals

\section{Crossref do) 81 Google}

Accepted25 $5^{\text {th }}$ May, 2021 \& Published 31 ${ }^{\text {th }}$ May, 2021

to the effectiveness of the work of art [2].

The social factor of the image of the "orphan child" in the literature arises from the writer's attitude to social life, to reality. The writer is not indifferent to the events of his time. Social life influences fiction. Problems of social environment, period, and society do not bypass fiction. At a time when the problem of orphan hood has become a major social problem, the character of the "orphan child" has entered the literature. Through the image of the "orphan child" the impact of the social environment on the child's psyche and development, the impact on the upbringing of the child was influenced by the main problems. Orphans in the community are cared for, stroking their heads, wandering the streets to see the execution of the houses that show mercy, including a thousand and one hardships to spend a day of life. There have been children who have overcome these problems, and there have been those who have not. How many orphans have taken to the streets, such as theft, robbery, kidnapping, how many have died prematurely. Such a social problem cannot be ignored by the literature. In fiction, when talking about the individual factor of the character of the "orphan child", first of all, it is observed that the creator is closer to the image. Creative personalities can be seen in the images of works of art. In such a play, the writer's life, pains, and mental states are absorbed. This brings the reader closer to the fiction and makes them feel deeper. The individual factor in the image of the "Orphan Child" in the work of art can be attributed to G. Gulam's "Shum bola" and " Mening o'g'rigina bolam".

G. Gulam was born at the dawn of the twentieth century, when social storms were flourishing, and he found his place in its ranks. In childhood, there will be characteristic predictions of events that will affect a person's entire later life that will continue, that will determine the true nature of adult life. This orphanage influences the later life of G. Gulam, who was orphaned early, his choice of a career, his life, and the essence of his work. The original source of the great orphan hood formed in him was childhood. In the works of Gafur Gulam, the main aspirations of the children of that time, their high spiritual worlds, manners, and ethics became the main theme. The essence of the story "Shum bola", which introduced G. Gulam to the whole world and aroused the love of the people for him, is the vision of orphan hood, orphan wandering, aspirations to get rid of orphan hood, and overcome it. In G. Gulam's works, orphan hood is closely connected with the feelings of fatherhood, and one comes from the other. Protecting the orphans from abuse, humiliation, oppression and oppression has become a leading theme in the author's work. Literary critic I. Gafurov writes about it: "G. Gulam writes about the fate of orphans and orphans with unparalleled sympathy because he knows what orphan hood is better than anyone else"[3].

The main theme in G. Gulam's poems is the theme of orphan hood. While explaining to children what orphan hood is, G. Gulam was able to increase the impact of his poems by recalling his bitter orphan hood. For example, the poem "You are not an orphan" contains the following lines:

... I grew up an orphan,

Oh, this orphan...

Oh, my poor soul.

It worth saying,

To stroke my head,

A kind hand,

A sweet word is as expensive as bread,

I was human,

Human child...

From this we understand that the poet is an 
CURRENT RESEARCH JOURNAL OF PHILOLOGICAL SCIENCES 2(5): 43-47,

May 2021 DOI: https://doi.org/10.37547/philological-crjps-02-05-12

ISSN 2767-3758

(C)2021 Master Journals

\section{Crossref do) 81 Google}

Accepted25 $5^{\text {th }}$ May, 2021 \& Published 31 $1^{\text {th }}$ May, 2021

orphan, that he does not have a loving hand to caress his head, and that being a human being is not enough to live among human beings.

There is reason to believe that G. Gulam portrayed the fate of his orphanhood in the image of a naughty child. In particular, Said Ahmad in his book "Yo'qotganlarim va topganlarim", along with his memoirs about the author, talks about the creation of the story "The Shum bola" and relies on genetic analysis. In the analysis, we see that the character of the "Shum bola" is related to the writer's personality.

The protagonist of the story "Shum bola" The Mischievous Boy is not called by a certain name, but when he calls him "Shum bola" it makes sense. Not one child, but many such orphans. The naughty child is portrayed as a common character of "orphans" in society as a whole. The children of Omon, Turobboy, Yuldosh, Husni, Salih, Abdulla, Polatkhoja, and Miraziz in the story have similar destinies. Omon is separated from his mother, Yuldash from his parents, and Mischievous Boy from his father. G. Gulam Shum sees the bitter fate of the image of the "Orphan Child" in the image of a Mischievous boy and interprets it artistically. In the story "Shum bola" G. Gulam portrayed the image of "Orphan boy" in a deep artistic pathos. "Caring for children, orphans, the oppressed, being compassionate and kind is called paternalism. The fact that this paternalism has risen to a great level of humanity in G. Ghulam can be observed from the beginning to the end of his work. The content features of a number of other motives and creative directions are rooted in the work of G. Gulam from the knowledge and feeling of being a father to the people, and especially to the younger generation... In addition, "Didn't "Shum Bola" raise Uzbek prose to the level of a great life, such as Huckle Berry Finn and The Adventures of Tom Sawyer, the pride of American literature?" [4] This masterpiece brought the joyous and painful adventures of an orphan to the scale of the Rablezian adventures of mankind. "This work has become popular among the people in such a way.

While depicting the image of an orphan, G. Ghulam tries to put the protagonist in a funny situation. U.Normatov, a literary critic, said about the attitude of Sariboy Bolis, Eshan, Haji Bobo, and others to the mischievous boy: "The story depicts the real life of the people of that time, the life of the people is embodied in all its facets, details and colors in front of us" [5]. So, it is clear that the writer has a basic, clear purpose behind the comic portrayal of the naughty boy. In the case of a miserable child, orphanhood is a reality, a bitter reality of life. He, too, waited for salvation from those around him too, he looked around with a pleading look in search of refuge, but at that time the society did not lend him a helping hand, did not show him the right way, and as a result, the naughty boy fell into crooked paths. He knew it was a mistake, but there was no way to turn back. There is no one to lean on.

In the story "Shum bola" the reality is described through the fate and point of view of these naughty boys. The naughty boys understand and evaluate life events based on their age, consciousness, worldview, and life experience. And the reader, looking at the reflection of life in the mirror of the soul, draws his own conclusions, feels the writer's intentions ... The adventurous nature of the plot, the fact that the protagonists travel from neighborhood to neighborhood, from village to village, in itself leads to the inclusion of many episodic heroes in the work.

Literary critic Suvon Meli has revealed some of the character traits of the naughty boy's character. Critic calls the boy a "native artist, an artist of reality" because of his comic situations [6]. "By the way, the whole boy's behavior is like a mysterious rebellion against the orphan," he said. He acts with revenge and pain in his heart". 
CURRENT RESEARCH JOURNAL OF PHILOLOGICAL SCIENCES 2(5): 43-47,

May 2021 DOI: https://doi.org/10.37547/philological-crjps-02-05-12

ISSN 2767-3758

(C)2021 Master Journals

\section{Crossref do) 81 Google}

Accepted25 $5^{\text {th }}$ May, 2021 \& Published 31 ${ }^{\text {th }}$ May, 2021

[7]

S. Meli's term "comic catharsis" is appropriate in expressing the inner sufferings and feelings of the image of the "orphan child". In other words, in the story "Shum bola" there is a pain in the layer of laughter, "So, comic catharsis means the disappearance of worldly suffering through laughter". Actually, "It is a great art to express two absolutely opposite feelings in one play, in the image of a hero." There is a nameless, bodyless pain in the depths of the seemingly endless joy in the play, which testifies to the quality of humor in "Shum bola," says S. Meli [8]. There are some inconsistencies in the literary and theoretical views of U. Normatov and S. Meli. U.Normatov said that the word "Naughty" in our native language has dozens of meanings, such as very funny, rebellious, arbitrary, cunning, sly, rebellious, ignorant, clever, stupid, sly, complicated, and a fierce person who survives situations[9] while Suwon Meli emphasizes the courage and ingenuity of the Naughty boy. Summarizing their thoughts, we discover that the Naughty boy has both positive and negative traits at the same time. In other words, the character of a Naughty boy is a clever, quickwitted, clever, resourceful, courageous, generous, smart, funny, cunning, curious "Orphan boy". It can be understood by the sentences: "Maybe this time he'll take revenge on me, and he'll leave, and I thought I'd be trapped here like a mouse in a bucket. I immediately emptied the bag and went inside" [10]. This cunning of the naughty boy is a traditional element, has been living with the folklores in the character of Nasriddin Efendi. Efendi's cunning, ingenuity, and eloquence made him famous among the people. Gulam also uses it to draw the image of an orphan. The similarity between these images is that behind their cunning, ingenuity, there are cases of impartial irony and masterful exit from the situation.

We look for good qualities in a naughty child. Perhaps the mischievous boy would not have been so popular among the people if only the good qualities of the boy had been artistically interpreted. We do not turn a blind eye to his work for the sake of life, he was forced to change his childhood and playfulness for the sake of survival. There were many times when he felt the pain and humiliation of his orphanhood, especially when he was beaten and insulted he often remembered his orphanhood.

Yes, ser, will you beat an orphan, is there slander to my service, ser? I cried, "said the mischievous boy. What feelings he felt at that time, even if the orphans had a full stomach and clothes, it would not be possible to fill their half-hearts by removing the "mark" of "orphanhood" on them. Therefore, it is not appropriate to judge a child by his or her appearance. He also has pains, sufferings, thoughts, dreams, and aspirations. The influence of society and the social environment on the upbringing of orphans is significant. We can see this in the case of the mischievous boy, the environment around the mischievous boy was "unhealthy". For example, the circles he fell into: Haji Bobo, Eshan, the thieves, Sariboy Bolis were "unhealthy." Their behavior, adapts the mischievous boy to this environment, to an unhealthy lifestyle. The hardships of life forced the mischievous boy to live like this. Not only the mischievous boy but also the children around him.

In short, the mischievous boy can be called an "orphan child" with a multifaceted nature. The contradictions in human nature are also reflected in the work of Gafur Gulam in the image of the "Orphan Child". The behavior of a naughty child, depending on the situation, creates differences in his nature. This can be explained as follows: First of all, the mischievous boy has a comic character, and the Shum child again has the characteristics of a Master who lives in folklore. This also shows that Shum has a flawless, cunning pure laughter.

Second, it is possible to observe a state of grief in 
CURRENT RESEARCH JOURNAL OF PHILOLOGICAL SCIENCES 2(5): 43-47,

May 2021 DOI: https://doi.org/10.37547/philological-crjps-02-05-12

ISSN 2767-3758

(C)2021 Master Journals

Crossref doi 81 Google

Accepted25 ${ }^{\text {th }}$ May, 2021 \& Published 31 ${ }^{\text {th }}$ May, 2021

which the mischievous boy laughs behind the innocent laughter. We called it "comic catharsis" as the words of literary critic S. Meli. As the author's main focus is on laughter, his endless sorrows pass unnoticed to readers. The state of pure grief is not directly expressed in the image of the naughty child. The naughty irony of the naughty child is a sign of understanding his true condition. So, The mischievous boy is a bright image of the Uzbek image of an orphan.

Instead of the last word, it can be said that the image of The mischievous boy has both funny and sad character at the same time. This shows that G. Gulam effectively used both comic and sentimentality in depicting the image of the the Mischievous boy. The bitter reality of life in the case of a naughty child is mixed with high art that he suffers a lot because of orphanhood. The adventures of a naughty boy are an excuse. The author reveals the social life of the regions through these adventures, that is, through the disgusting situations in which Shum's childhood fell. The play depicts the tragic consequences of the First World War, the helplessness of the people, and the wandering of children on the streets. The play's depiction of the proliferation of madmen is also a testament to how difficult life can be. They are not crazy for nothing, the hardships of the times, the violence of the system make them do it. Life is bitter, but you have to struggle to survive. The character of an orphan is a teenager with pain hidden in a noisy child. There is a painful and tragic fate behind his seemingly funny life. The play depicts the fate of an orphan on the basis of a combination of reallife and art.

\section{REFERENCES}

1. Sarimsoqov B. Badiiylik asoslari va mezonlari. -T.: 2004, B.13.

2. Jo'raqulov U. Hududsiz jilva. - T.: 2006, B.18.
3. G'afurov I. Mangu latofat. - T.: 2008, B. 116.

4. G'afurov I. Mangu latofat. - T.: 2008, B. 116.

5. Normatov U. Ijod sehri. - T.: 2007, B.148.

6. Meli S. Komik katarsis//O'zbek tili va adabiyoti. - 2003. - №2, B.22.

7. Meli S. Komik katarsis//O'zbek tili va adabiyoti. - 2003. - №2, B.25.

8. Meli S. Komik katarsis//O'zbek tili va adabiyoti. - 2003. - №2, B.28.

9. Normatov U. Ijod sehri. - T.: 2007, B.150.

10. G'.G'ulom. Shum bola. -T.: 2004. B. 